\title{
Effectiveness Analysis of the Application of the
} Failure Mode and Effect Analysis Method with \section{Failure Defense Task for Reliability Management Improvement in Sea Water Desalination System of PLTU Paiton Baru (1 X 660 MW)}

\author{
Ahmad Fajar Ridlo ${ }^{1}$
}

\begin{abstract}
PT PJB UBJOM Paiton Baru as the $O \& M$ Service Manager of PLTU Paiton Baru 1 x 660 MW has approved the concepts and policies of PT PJB on the Reliability Management Program using the FMEA method along with the Failure Defense Task (FDT). However, the FMEA method that has been impelemented not yet effective. First, because first has not been aligned with existing reference books and international journals where there is no process of determining the value of Severity (S), Occurrence (O), and Detection (D), and calculation of Risk Priority Number (RPN), and the process of decreasing the risk value by using the right Failure Defense Task. Second, based on the evaluation of the results of the site visit at UBJOM Paiton Baru for Main Equipment and Sub Equipment for Seawater Desalination Systems, among 21 Sub-Systems in the Seawater Desalination System using Reverse Osmosis Technology, only 7 Sub-Systems have conducted The FMEA and FDT Workshop or 33.3\% of the total Sub-Systems, and 14 Sub- Systems have not conducted FMEA and FDT Workshops or $66.6 \%$ of the total Sub-Systems.
\end{abstract}

Third, based on further research on the results of the FMEA and FDT Workshop at UBJOM Paiton Baru in 5 Sub- systems namely Mechanical Accelerated Clarifier, Air Scouring Filter, Self Cleaning Filter, Ultra Filtration Device, Energy Recovery Device, that for determining Failure Mode sourced from Manual Book, PM Base, Existing Unit, and Browsing the Internet, so there is no data in identifying Failure Mode. Then FDT for interval $1 Y$ (Annually) is an Overhaul with several types of inspections that have not been implemented / executed for Mechanical, Electrical, Control \& Instrumentation Skills which include Assembly and Disassembly, Visual Inspection, repair or replacement if needed according to the results of Visual Inspection, testing, I / O Check, and calibration, so that FDT with Frequency 1Y (Annually) has not been effective.

Meanwhile, based on the results of the Workshop on Failure Mode and Effect Analysis (FMEA) and FDT which has been aligned with reference books and international journals, by calculating the Risk Priority Number (RPN) on Failure Mode Failure Mode identified and assessed Severity, Occurrence and Detection Levels for 6 Sub Systems, 14 Failure Modes have been

${ }^{1}$ Ahmad Fajar Ridlo is with Project Management, Department of Technology Management, Faculty of Business and Technology Management, Institut Teknologi Sepuluh Nopember, Surabaya, 60264, Indonesia. E-mail: fajar.ridlo@yahoo.com mapped with risk categories of Major Risk, 31 Failure Modes with risk categories of Moderate Risk and 2 Failure Mode with risk categories of Minor Risk according to Ranking based on Risk Priority Number.

From 47 Failure Modes that have been mapped risk categories, have been submitted for approval Proposed Maintenance Strategy as an effort in recalculating the value of Risk Priority Number (RPN), based on the results of Review and Evaluation of FMEA and Existing FDT Workshop Data Results and Analysis of Equipment Condition.

Keywords-FMEA, FDT, Severity (S), Occurrence (O), Detection (D), RPN, Failure Mode, Sub System, Risk Category, Proposed Maintenance Strategy.

\section{INTRODUCTION}

PT PJB's policies that have been made related to Generating Governance In Accordance with Policy of PT Pembangkitan Jawa Bali No. 105.K / 010 / DIR / 2007 concerning the Tata Kelola Pembangkitan PT Pembangkitan Jawa Bali and continued with the Policy of PT Pembangkitan Jawa Bali No. 122.K / 020 / DIR / 2016 concerning the Implementasi Manajemen Aset Pembangkitan PT Pembangkitan Jawa Bali, in Chapter 4.5 concerning Reliability Management it is explained that the purpose of Reliability Management is to ensure that there are no failures in all equipment when operated, not derating with optimum costs, by minimizing or eliminating failures and their causes, and optimizing them, with Work Flow as shown in the Figure 1.

Error! Objects cannot be created from editing field codes. Figure 1. Work Flow Reliability Improvement Program

There are 2 problems that underlie the writing of this thesis paper, the first has been a problem in the Sea Water Desalination System which caused the unit to experience electricity production disruption due to lack of Make Up Water products in the Sea Water Desalination Plant in Indramayu PLTU and Pacitan PLTU, and potentially occur 
in Sea Water The Paiton Baru PLTU Desalination System, and the second is the concept and policy of the Reliability Improvement Program (Reliability Management) using the FMEA method, and RCFA along with the Failure Defense Task. However, the FMEA method that has been compiled has not been aligned with existing reference books and international journals where there is no process of determining Severity (S), Occurrence (O), and Detection (D) and calculation of risk value (RPN), and is not visible the process of reducing the risk value by using the right Failure Defense Task.

The purpose of writing this paper is to assess the effectiveness of the application of the FMEA method along with the Failure Defense Task that has been produced through a workshop mechanism, for Reliability Management improvement in Main Equipment and Sub Equipment in the New Paiton PLTU Sea Water Desalination System (1x660 MW) with:

1. Identification, evaluation, and analysis of Damage Report Data (Incident Log/Service Request Data on Maximo CMMS) and FMEA documents along with Failure Defense Task (Current Maintenance Strategy) that have been produced through existing workshop mechanisms.

2. Comparing with international journals and reference books related to the methods used and harmonizing.

3. Propose a new maintenance strategy to reduce the existing risks so that there will be no damage to the equipment (Main and Sub Equipment) Sea Water Desalination System which causes the supply of Make Up Water boiler to be disrupted and result in the stop of the electricity production process beyond what was planned.

\section{REVIEW OF LITERATURE AND BASIC THEORY}

There are several system modeling methods for reliability analysis, some of which are:

1. Reliability Block Diagram Method that includes the relationship of the Series System, Parallel System, Standby System, Share Load System, and Complex System.

2. Logic-Based Boolean Methods, including:

- Method of Fault Tree and Success Tree and Construction and Evaluation of the tree method.

- Event Tree methods which include multi system design modeling and complex systems in which individual units must work in chronological ways (in a row) or approach chronologically to achieve a mission.

3. Failure Mode and Effect Analysis (FMEA) Method

4. Master Logic Diagram (MLD) Analysis Method

In this paper discussed is the Failure Mode and Effect Analysis Method, an engineering technique used to define, identify, and eliminate known and / or potential failures, problems, errors, etc. from the system, design, process, and
/ or service before they reached the customer, which was the main topic in writing this paper[1].

Failure Mode and Effect Analysis (FMEA) is a method designed to:

1. Identify and fully understand the possibility of failures mode and their causes, and the effects of failure on the system or end user, for a particular product or process.

2. Assessing risks associated with identified modes, effects, and causes of failure, and prioritizing problems for corrective actions.

3. Identify and carry out corrective actions to address the most serious problems[2].

There are three components that help determine the priority of failure, namely Severity $(\mathrm{S})$, Occurence $(\mathrm{O})$, and Detection(D)[3].

For the next RCM produces a task for a scheduled maintenance program that logically anticipates specific failure modes that can effectively do the following things:

1. Detect failure or damage earlier to take corrective action faster and with the smallest possible interference.

2. Eliminate the causes of some failures or damage before they occur.

3. Eliminate the causes of some failures or damage through design changes.

4. Identify damage that can be safely allowed to occur [4].

RCM has 7 basic stages that meet the criteria that have been issued by the standards of the Society for Automotive Engineers (SAE), the 7 Basic Stages as above can be described in RCM Process Flow and RCM Decision Logic as shown in Figure 2.

\section{RESEARCH METHODS}

Stages of research are made based on the FMEA method work procedures that are tailored to the actual needs and conditions in the field. The planned research stages are in Figure 3.

\section{RESEARCH RESULTS AND DISCUSSION}

A. Data Analysis of Workshop Results of FMEA and FDT Existing Sea Water Desalination System UBJOM Paiton Baru

Based on the analysis of the results of the site visit at UBJOM Paiton Baru PLTU on Main Equipment and Sub Equipment Sea Water Desalination System, that of the 21 Sub Systems in the Sea Water Desalination System that use Reverse Osmosis technology, 7 Sub-Systems have been carried out by FMEA Workshop and FDT or 33.3\% of the total Sub System, and 14 Sub Systems have not been done FMEA and FDT Workshop or $66.6 \%$ of the total Sub System. From the 7 Sub Systems that have been carried out by the FMEA and FDT Workshop, further research is carried out on 5 Sub-Systems, namely:

1. Mechanical Accelerated Clarifier

2. Air Scouring Filter

3. Self Cleaning Filter 
4. Ultra Filtration Device

5. Energy Recovery Device

plus 1 Sub System that has not been done by the FMEA and FDT Workshop that has data on reports of improper damage / failure, namely the 1st Pass RO Cartridge Filter.

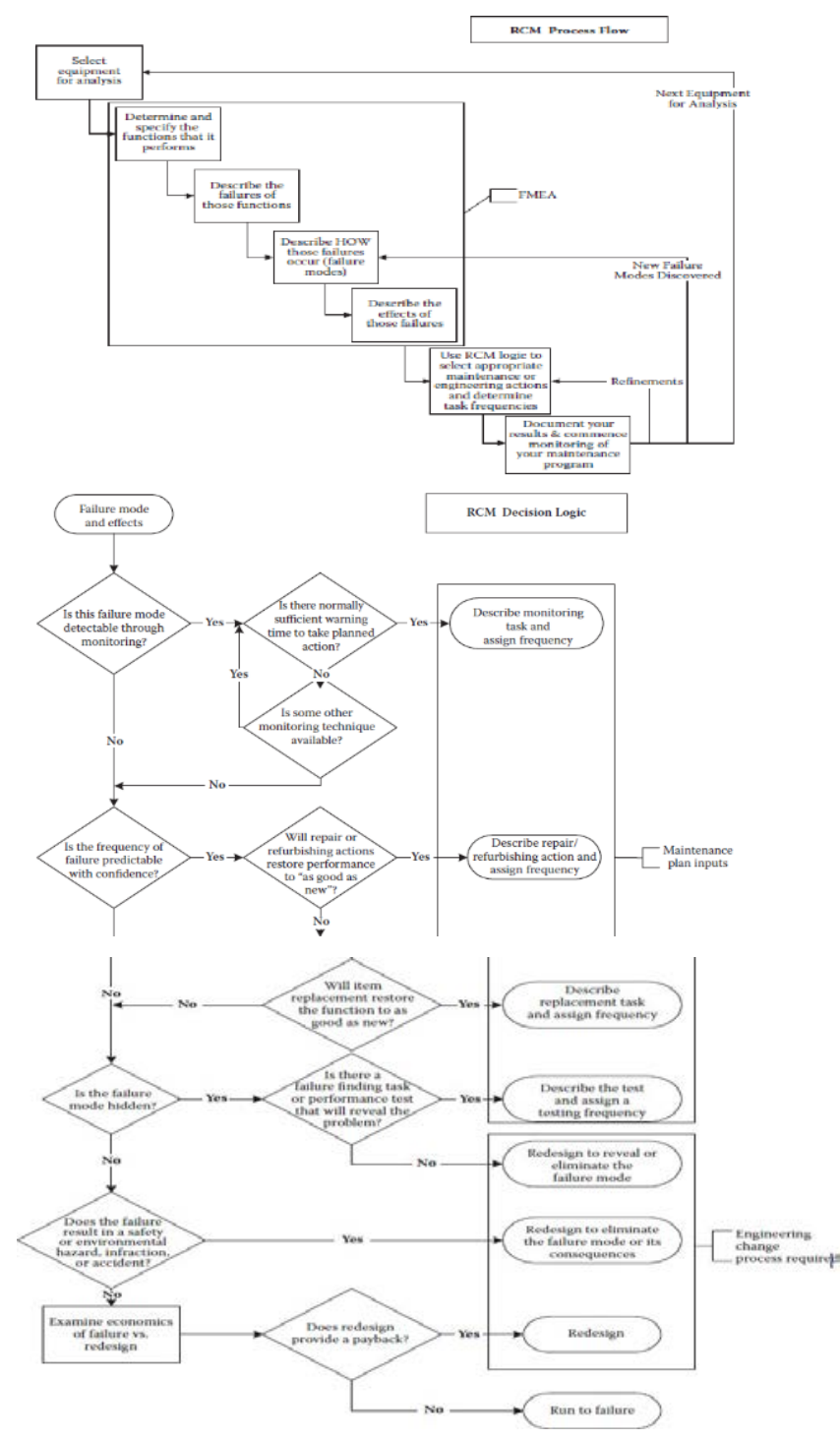

Figure 2. RCM Process Flow dan RCM Decision Logic

B. Review and Evaluation of Workshop Results of FMEA and FDT Workshop on 5 Sub Systems

Based on further research on the results of the FMEA and FDT Workshop on 5 Sub-systems namely Mechanical Accelerated Clarifier, Air Scouring Filter, Self Cleaning Filter, Ultra Filtration Device, the following things can be Energy Recovery Devices:

1) FMEA Workshop conducted by UBJOM Paiton Baru PLTU, has not identified Severity, Occurrence, and Detection rates, as well as calculation of Risk Priority Number (RPN) as is generally done according to the literature used (reference books and international journals).

2) To determine Failure Mode is not based on historical data from Operator Damage Reports, but the source is based on Manual Book, PM Base, Existing Unit, and Browsing the Internet, so there is no data in identifying Failure Mode.

3) For Failure Defense Task with 1Y interval (Annual), that is an Overhaul with several types of inspections that have not been implemented / executed (there is no Standard Job Annual Inspection) for Mechanical, Electrical, Control \& Instrumentation scope which includes Dissasembly, Visual Inspection, repair or replacement if required according to the results of the Visual Inspection, testing, I / O Check, and calibration, so that FDT with Frequency $1 \mathrm{Y}$ has not been effective.

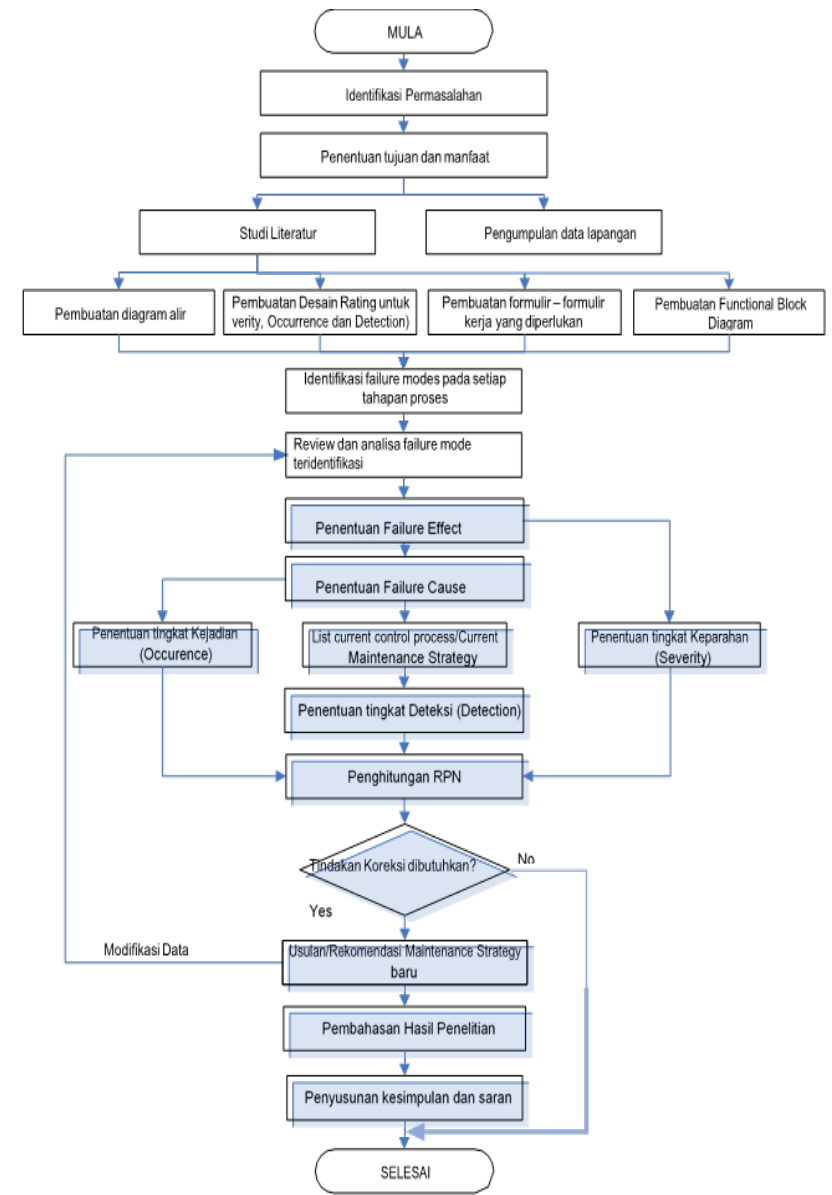

Figure 3. Stage of Research

Based on the Evaluation Results on Data of Authorized Engineering Staff Training as the FMEA Owner Workshop and FMEA Implementation Policy Guidelines, it can be stated that:

1. Based on the evaluation of Training data from the Administration and HR Department, the Engineering Supervisors and Staff especially those who are 
The $1^{\text {st }}$ International Conference on Business and Management of Technology (IConBMT)

August 3rd 2019, Institut Teknologi Sepuluh Nopember, Surabaya, Indonesia

authorized to carry out the workshop process and FMEA and FDT implementation on the Sea Water Desalination System, namely System Owner Common \& Auxiliary Sub Fields have never received training on FMEA .

2. Based on the evaluation of the contents of the Guidelines for Policy of PT Pembangkitan Jawa Bali No. 122.K/020/DIR/2016 concerning Implementasi Manajemen Aset Pembangkitan PT Pembangkitan Jawa Bali, in Chapter 4.5 concerning Reliability Management, indeed there is no detailed guidance regarding Failure Mode \& Effect Analysis (FMEA) Standard Format that must be used, and how the analysis process.

C. Design the Severity, Occurrence, Detection (SOD) Rating and Risk Map according to the calculation of Risk Priority Number (RPN)

Then make the Severity Design, Occurrence, Detection (SOD) Rating and Risk Map according to the calculation of the Risk Priority Number (RPN).

1) Design Severity Rating with Scale 1-10

According to the results of the evaluation of the reference book[3] and by looking at the condition of the Physical Assets being analyzed, the Design of Severity Rating is made with a Scale of 1-10 as shown in Table 1 below:

TABLE 1.

DESIGN SEVERITY RATING WITH SCALE 1-10

\begin{tabular}{|c|c|c|}
\hline \\
\hline Dampak (Effect) & \begin{tabular}{|c|}
$\begin{array}{c}\text { Nilai } \\
\text { (Rating) }\end{array}$ \\
\end{tabular} & Kriteria \\
\hline None & 1 & Tidak ada dampak ( No Effect) \\
\hline $\begin{array}{l}\text { Sangat Sedikit } \\
\text { (Very Slight) }\end{array}$ & 2 & $\begin{array}{l}\text { Failure Mode yang menyebabkan pelanggan tidak terganggu, Dampak terhadap } \\
\text { Kinerja Produksi - Sangat Sedikit, kesalahan yang tidak vital tercatat }\end{array}$ \\
\hline $\begin{array}{l}\text { Sedikit } \\
\text { (Slight) }\end{array}$ & 3 & $\begin{array}{l}\text { Failure Mode yang menyebabkan pelanggan sedikit terganggu, Dampak terhadap } \\
\text { kinerja Produksi - Sedikit, kesalahan yang tidak vital selalu tercatat }\end{array}$ \\
\hline $\begin{array}{l}\text { Kecil } \\
\text { (Minor) }\end{array}$ & 4 & $\begin{array}{l}\text { Failure Mode yang menyebabkan pelanggan terganggu, Dampak terhadap } \\
\text { Kinerja Produksi - Kecil, kesalahan tidak membutuhkan perbaikan (repair) }\end{array}$ \\
\hline $\begin{array}{l}\text { Sedang } \\
\text { (Moderate) }\end{array}$ & 5 & $\begin{array}{l}\text { Failure Mode yang menyebabkan pelanggan beberapa kali tidak puas, Dampak } \\
\text { terhadap Kinerja Produksi - sedang, ke pada part yang tidak vital membutuhkan } \\
\text { perbaikan (repair) }\end{array}$ \\
\hline $\begin{array}{l}\text { Berarti/Penting } \\
\text { (Significant) }\end{array}$ & 6 & \begin{tabular}{|l} 
Failure Mode yang menyebabkan Pelanggan sering tidak nyaman, Kinerja \\
Produksi menurun tetapi masih bisa beroperasi dan aman. Beberapa part yang \\
tidak vital tidak beroperasi
\end{tabular} \\
\hline $\begin{array}{l}\text { Besar } \\
\text { (Major) }\end{array}$ & 7 & $\begin{array}{l}\text { Failure Mode yang menyebabkan Pelanggan tidak puas, Kinerja Produksi } \\
\text { sungguh - sungguh terpengaruh namun masih bisa berfungsi dan aman. }\end{array}$ \\
\hline $\begin{array}{l}\begin{array}{l}\text { Sangat Besar } \\
\text { (Extreme) }\end{array} \\
\end{array}$ & 8 & $\begin{array}{l}\text { Failure Mode yang menyebabkan Pelanggan sangat tidak puas, Produksi tidak } \\
\text { beroperasi namun aman, sistem tidak beroperasi. }\end{array}$ \\
\hline $\begin{array}{l}\text { Serius } \\
\text { (Serious) }\end{array}$ & 9 & $\begin{array}{l}\text { Failure Mode yang berpotensi memberikan dampak yang berbahaya, bisa } \\
\text { menghentikan produksi tanpa kecelakaan, serta berpotensi menyebabkan } \\
\text { ketidakpatuhan terhadap regulasi pemerintah }\end{array}$ \\
\hline $\begin{array}{l}\text { Berbahaya } \\
\text { (Hazardous) }\end{array}$ & 10 & $\begin{array}{l}\text { Failure Mode yang memberikan dampak yang berbahaya, kegagalan/kerusakan } \\
\text { yang tiba - tiba yang berhubungan dengan keselamatan, serta menyebabkan } \\
\text { Ketidakpatuhan terhadap regulasi pemerintah }\end{array}$ \\
\hline
\end{tabular}

2) Design Occurrence Rating with Scale 1 - 10

According to the results of the evaluation of the reference book [1], [3] and by looking at the condition of the Physical Assets being analyzed, the Occurrence Rating design is made with a Scale of $1-10$. To identify the frequency of each cause with Scale 1 - 10, using Cummulative Number of Failure per 1000 existing data (CNF / 1000) or the number of Failure Frequency for each $\mathrm{N}$ data, as in Table 2 below:

TABLE 2.

Design OCCURENCE RATING WITH SCALE 1- 10 Skala 1- 10 Tingkat Kejadian (Occurrence)

\begin{tabular}{|c|c|c|c|c|}
\hline $\begin{array}{c}\text { Kejadian } \\
\text { (Occurrence - 0) }\end{array}$ & $\mid \begin{array}{c}\text { Nilai } \\
\text { (Rating) }\end{array}$ & Kriteria & $\begin{array}{c}\text { CNF/1000 } \\
\text { (Cummulative } \\
\text { Number of Failure) }\end{array}$ & $\begin{array}{c}\text { Failure Frequency } \\
\text { (frekuensi } \\
\text { Kegagalan/kerussakan) }\end{array}$ \\
\hline $\begin{array}{l}\text { Hampir tidak pernah } \\
\text { (Almost Never) }\end{array}$ & 1 & $\begin{array}{l}\text { Kegagalan/kerusakan jarang, Riwayat menunjukkan tidak ada } \\
\text { kegagalan/kerusakan }\end{array}$ & $<0.00058$ & $<1$ in 150000 \\
\hline $\begin{array}{l}\text { Songot Jauh/jarng } \\
\text { (Remote) }\end{array}$ & 2 & Jumlahkemungkinan kegagalan/kerusakan jarang & 0,0058 & 1 in 150000 \\
\hline $\begin{array}{l}\text { Sangat Sedikit } \\
\text { Nery Slight) }\end{array}$ & 3 & Kermungkinan kegagalan/kerusakan sangat sedikit & 0,0053 & 1 in 15000 \\
\hline $\begin{array}{l}\text { Sedikit } \\
\text { (Slight) }\end{array}$ & 4 & Jumlsh kemungkinan kegogalan/kerussokan sedikit & 0,46 & 1 in 2000 \\
\hline $\begin{array}{l}\text { Rendah } \\
\text { (Low) }\end{array}$ & 5 & Jumlah kemungkinan kegagalan/kerusakan kadang - kadang & 2,7 & 1 in 400 \\
\hline $\begin{array}{l}\text { Sedang } \\
\text { (Medium) }\end{array}$ & 6 & Jumlah kemungkinan kegagalan/kerusakan sedang & 12,4 & 1 in 80 \\
\hline $\begin{array}{l}\text { Cukup Tinegi } \\
\text { (Moderotey High) }\end{array}$ & 7 & Jumlah kemungkinan kegagelan/kerusakan cukupp tinggi & 46 & $\operatorname{lin} 20$ \\
\hline $\begin{array}{l}\text { Tingegi } \\
\text { (High) }\end{array}$ & 8 & Jumlah kemungkinan kegagalan/kerusakan tingsi & 134 & 1 in 8 \\
\hline $\begin{array}{l}\text { Sangat Tingsi } \\
\text { (Nery High) }\end{array}$ & 9 & Jumloh kemungkinon kegogalon/kerusokan songat tinggi & 316 & $1 \operatorname{lin} 3$ \\
\hline $\begin{array}{l}\text { Hampir Pasti } \\
\text { (Aimost Certain) }\end{array}$ & 10 & $\begin{array}{l}\text { Kegagalan/kerussakan hampii pasti. Riwayat } \\
\text { kegagalan/kenusakan acs mulai desain sebelumnya. }\end{array}$ & $>316$ & $>1 \operatorname{lin} 2$ \\
\hline
\end{tabular}

3) Design Detection Rating with Scale 1 - 10

According to the results of the evaluation of the reference book [3] and by looking at the condition of the Physical Assets being analyzed, the Design of Detection Rating is made with a Scale of 1-10 as shown in Table 3 below:

TABEL 3.

\begin{tabular}{|c|c|c|}
\hline \multicolumn{3}{|r|}{ N DETECTION RATING WITH SCALE $1-10$} \\
\hline $\begin{array}{c}\text { Deteksi } \\
\text { (Detection-D) }\end{array}$ & $\begin{array}{c}\text { Nilai } \\
\text { (Rating) }\end{array}$ & Kriteria \\
\hline $\begin{array}{l}\text { Hampir pasti } \\
\text { (Almost Certain) }\end{array}$ & 1 & Pengendalian saat ini hampir selalu akan mendeteksi kegagalan/kerusak \\
\hline $\begin{array}{l}\text { Sangat Tinggi } \\
\text { (Very High) }\end{array}$ & 2 & $\begin{array}{l}\text { Pengendalian saat ini kemungkinannya sangat tinggi akan mendeteksi } \\
\text { kegagalan/kerusakan }\end{array}$ \\
\hline $\begin{array}{l}\text { Tinggi } \\
\text { (High) }\end{array}$ & 3 & $\begin{array}{l}\text { Pengendalian saat ini kemungkinannya tinggi akan mendeteksi } \\
\text { kegagalan/kerusakan }\end{array}$ \\
\hline $\begin{array}{l}\text { Cukup Tinggi } \\
\text { (Moderately High) }\end{array}$ & 4 & $\begin{array}{l}\text { Pengendalian saat ini kemungkinannya cukup tinggi akan mendeteksi } \\
\text { kegagalan/kerusakan }\end{array}$ \\
\hline $\begin{array}{l}\text { Sedang } \\
\text { (Medium) }\end{array}$ & 5 & $\begin{array}{l}\text { Pengendalian saat ini kemungkinannya sedang akan mendeteksi } \\
\text { kegagalan/kerusakan }\end{array}$ \\
\hline $\begin{array}{l}\text { Rendah } \\
\text { (Low) }\end{array}$ & 6 & $\begin{array}{l}\text { Pengendalian saat ini kemungkinannya rendah akan mendeteksi } \\
\text { kegagalan/kerusakan }\end{array}$ \\
\hline $\begin{array}{l}\text { Sedikit } \\
\text { (Slight) }\end{array}$ & 7 & $\begin{array}{l}\text { Pengendalian saat ini kemungkinannya sedikit akan mendeteksi } \\
\text { kegagalan/kerusakan }\end{array}$ \\
\hline $\begin{array}{l}\text { Sangat Sedikit } \\
\text { (Very Slight) }\end{array}$ & 8 & $\begin{array}{l}\text { Pengendalian saat ini kemungkinannya sangat sedikit akan mendeteksi } \\
\text { kegagalan/kerusakan }\end{array}$ \\
\hline $\begin{array}{l}\text { Sangat Jauh } \\
\text { (Remote) }\end{array}$ & 9 & $\begin{array}{l}\text { Pengendalian saat ini kemungkinannya jauh akan mendeteksi } \\
\text { kegagalan/kerusakan }\end{array}$ \\
\hline $\begin{array}{l}\text { Hampir Tidak Mungkin } \\
\text { (Almost Impossible) }\end{array}$ & 10 & Tidak ada pengendalian untuk mendeteksi kegagalan/kerusakan \\
\hline
\end{tabular}

D. Design Risk Category Mapping Based On Severity, Occurrence, and Detection Rating (SOD Rating)

As a result of the evaluation of the reference book on Risk Priority Number (RPN) [2], a plot of Severity, Occurrence and Detection values can be made into the category of Low or Minor, Moderate, High or Major risk, as a basis for mapping using the Risk Matrix Three - Dimensional Matrix, as shown in Table 4 below: 
TABLE 4

Plots OF SEVERITy (S), OCCURRENCE (O), AND DETECTION (D) VALUES IN THE CATEGORY OF LOW OR MINOR, MODERATE, HIGH OR MAJOR RISKS

\begin{tabular}{|c|c|c|c|c|c|c|c|c|}
\hline $\begin{array}{c}\text { Nama } \\
\text { Variabel }\end{array}$ & $\begin{array}{l}\text { Tingkat } \\
\text { (Rating) }\end{array}$ & $\begin{array}{l}\text { Kategori Risiko } \\
\text { (Risk Category) }\end{array}$ & $\begin{array}{l}\text { Nama } \\
\text { Variabel }\end{array}$ & \begin{tabular}{|l} 
Tingkat \\
(Rating)
\end{tabular} & $\begin{array}{l}\text { Kategori Risiko } \\
\text { (Risk Category) }\end{array}$ & $\begin{array}{r}\text { Nama } \\
\text { Variabe }\end{array}$ & \begin{tabular}{|c|} 
Tingkat \\
(Rating)
\end{tabular} & $\begin{array}{l}\text { Kategori Risiko } \\
\text { (Risk Category) }\end{array}$ \\
\hline \multirow{11}{*}{ y } & 1 & \multirow{4}{*}{ Minor } & & 1 & \multirow{5}{*}{ Low } & \multirow{5}{*}{$\begin{array}{l}E \\
C\end{array}$} & 1 & \multirow{3}{*}{ High } \\
\hline & 2 & & & 2 & & & 2 & \\
\hline & 3 & & & 3 & & & 3 & \\
\hline & 4 & & & 4 & & & 4 & \multirow{2}{*}{ Moderate } \\
\hline & 5 & \multirow{3}{*}{ Moderate } & \multirow{2}{*}{$\begin{array}{l}o \\
c \\
c\end{array}$} & 5 & & & 5 & \\
\hline & 6 & & & 6 & \multirow{3}{*}{ Moderate } & \multirow{6}{*}{$\begin{array}{l}\mathrm{O} \\
\mathrm{N}\end{array}$} & \multirow{3}{*}{6} & \multirow{6}{*}{ Low } \\
\hline & & & \multirow{5}{*}{$\begin{array}{l}\mathrm{E} \\
\mathrm{N} \\
\mathrm{C} \\
\mathrm{E}\end{array}$} & & & & & \\
\hline & 7 & \multirow{4}{*}{ Major } & & 7 & & & & \\
\hline & 8 & & & 8 & \multirow{3}{*}{ High } & & 8 & \\
\hline & 9 & & & 9 & & & 9 & \\
\hline & 10 & & & 10 & & & 10 & \\
\hline
\end{tabular}

Making Mapping Design of RPN (RPN Mapping) according to the Results of Calculation of Risk Priority Numbers (RPN) using the Three Dimensional Matrix.

According to the results of the evaluation of the reference book about Risk Priority Number (RPN) [2] Risk Categorization with a value scale according to the results of the Category Value Plot, Low or Minor, Moderate, High or Major As shown in table 4 above and then mapping Risk Priority Number category according to scale based on the calculation results of $\mathrm{S} \times \mathrm{O} \times \mathrm{D}$ as the basis for mapping using the RPN Map - Three Dimensional Matrix, with 3 risk categories namely Minor Risk, Moderate Risk, and Major Risk as shown in Table 5 below:

TABLE 5.

MAPPING OF RISK PRIORITY NUMBER (RPN) CATEGORIES ACCORDING TO THE SCALE OF S X O X D CALCULATION RESULTS

\begin{tabular}{l|c|}
\hline Kategori Risiko (Risk Categorization) & Skala (Scale) \\
\hline Minor Risk & $1-124$ \\
\hline Moderate Risk & $125-342$ \\
\hline Major Risk & $343-1000$ \\
\hline
\end{tabular}

And according to the results of the evaluation of the reference book on Risk Priority Number [2], Mapping of RPN (RPN Mapping) Three-Dimensional Matrix using Matlab was made that illustrates the combination of 3 Variables Calculation of Risk Priority Number (RPN) which includes Severity Rating, Occurrence Rating, and Detection Rating, as a basis for taking appropriate action [2] as shown in Figure 4 below:

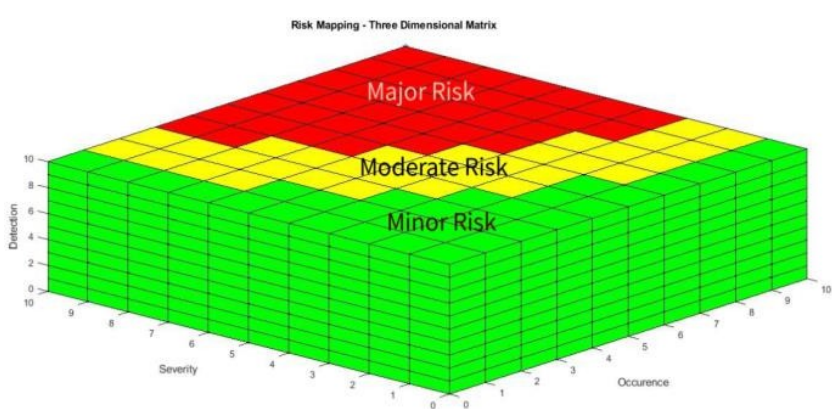

Gambar 4. Pemetaan RPN (RPN Mapping) - Three Dimensional Matrix 3 Varibel Severity (S), Occurrence (O), Detection (D) Menggunakan Matlab

E. Interview and Brainstorming Results through the Workshop Mechanism

The Interview and Brain Storming process was carried out with a Workshop Mechanism with the format of aligning with the Standard Society of Automotive Engineers SAE J1749.

From the historical data, brainstorming and open questionnaires were then carried out involving several participants from the Engineering Field, Maintenance Fields, and Operations Fields.

The next process is determining the new Maintenance Strategy proposal or recommendation, with Work Flow Process Implementation Workshop with Interview Mechanism and Brain Storming as shown in Figure 5 below:

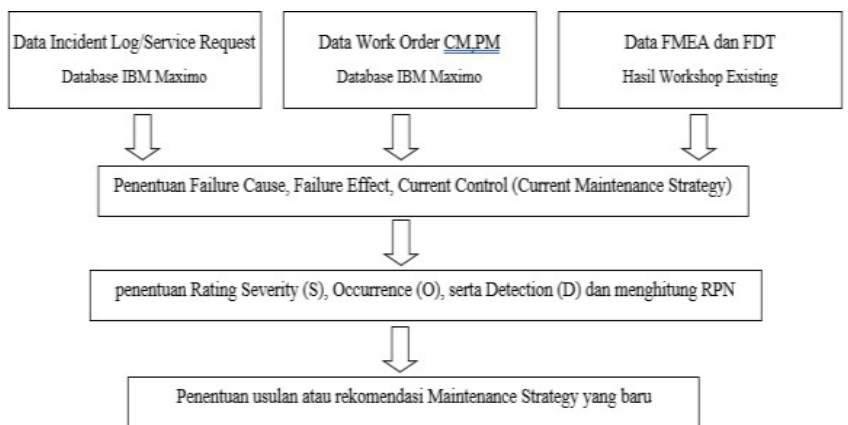

Figure 5. Work Flow Proses Pelaksanaan Workshop dengan Mekanisme Interview dan Brain Storming

The Interview and Brain Storming process through this Workshop mechanism was carried out in 6 Sub Systems which consisted of:

1. Mechanical Accelerated Clarifier

2. Air Scouring Filter

3. Self Cleaning Filter

4. Ultra Filtration Device

5. $1^{\text {st }}$ Pass RO Cartridge Filter

6. Energy Recovery Device

FMEA analysis is limited to providing maintenance strategy proposals in the sense that it is not until waiting for recommendations to be carried out and re-calculation of RPN as an attempt to reduce risk values, with Major Risk risk categories as shown in the following table: 
The $1^{\text {st }}$ International Conference on Business and Management of Technology (IConBMT)

August 3rd 2019, Institut Teknologi Sepuluh Nopember, Surabaya, Indonesia

TABLE 6.

ANALYSIS RESULT BASED ON INTERVIEW AND BRAIN STORMING FMEA THROUGH WORKSHOP MECHANISM IN THE SUB SYSTEM OF MECHANICAL ACCELERATED CLARIFIER

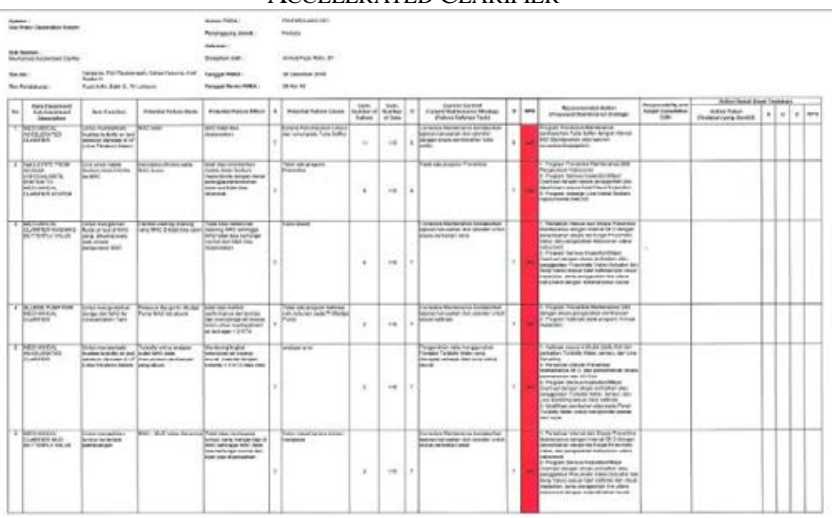

TABLE 7.

ANALYSIS RESULTS BASED ON INTERVIEW AND BRAIN STORMING FMEA THROUGH A WORKSHOP MECHANISM IN THE SUB SYSTEM OF AIR

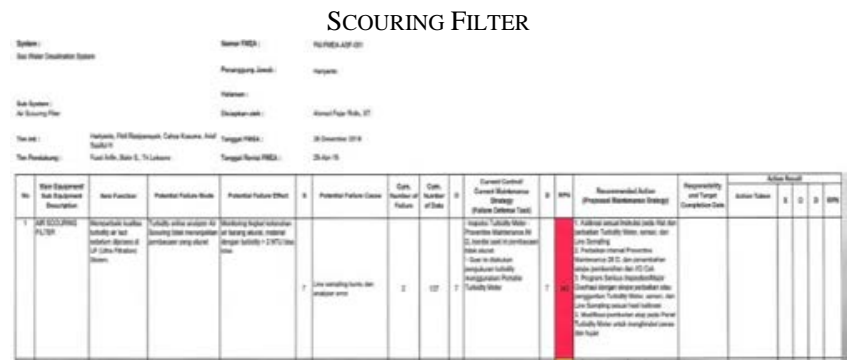

TABLE 8.

ANALYSIS RESULTS BASED ON INTERVIEW AND BRAIN STORMING FMEA THROUGH A WORKSHOP MECHANISM IN THE SUB SYSTEM OF SELF

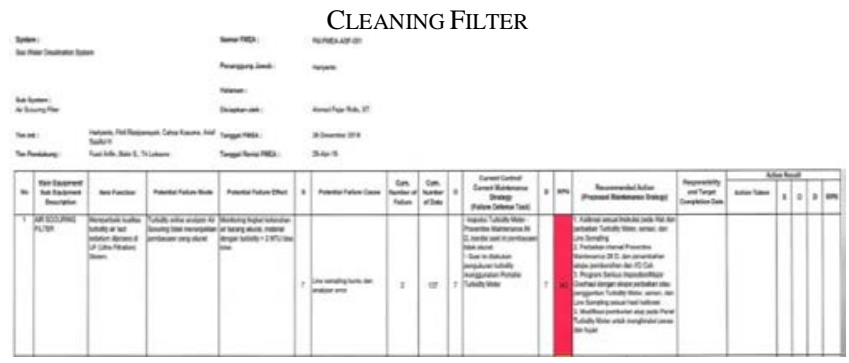

TABLE 9.

ANALYSIS RESULTS BASED ON INTERVIEW AND BRAIN STORMING FMEA THROUGH WORKSHOP MECHANISM ON SUB SYSTEM ULTRA FILTRATION

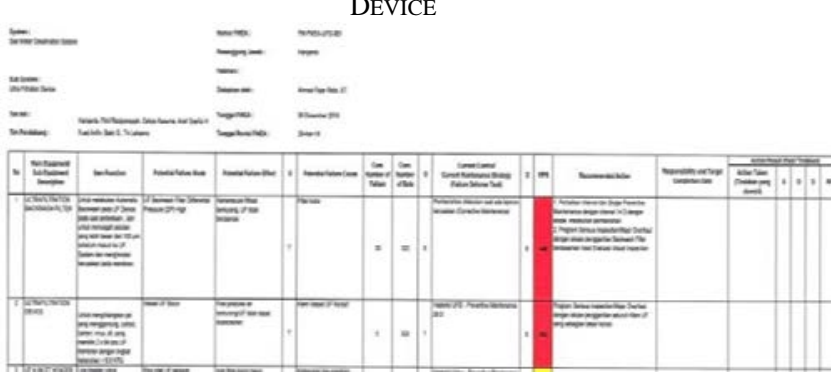

TABLE 10.

ANALYSIS RESULT BASED ON INTERVIEW AND BRAIN STORMING FMEA THROUGH WORKSHOP MECHANISM IN THE SUB SYSTEM OF $1^{\text {ST }}$ PASS RO

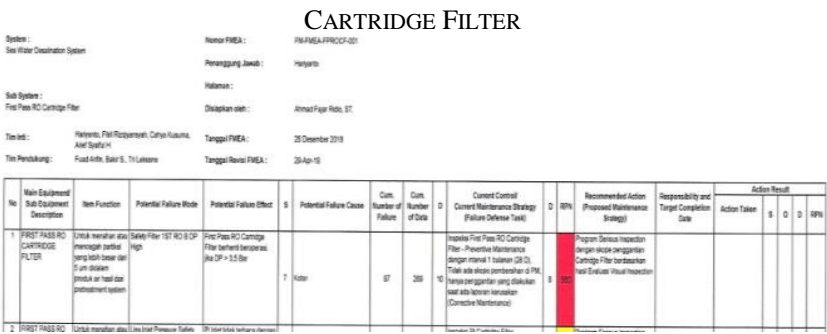

TABLE 11.

ANALYSIS RESULT BASED ON INTERVIEW AND BRAIN STORMING FMEA THROUGH WORKSHOP MECHANISM IN THE SUB SYSTEM OF ENERGY RECOVERY DEVICE

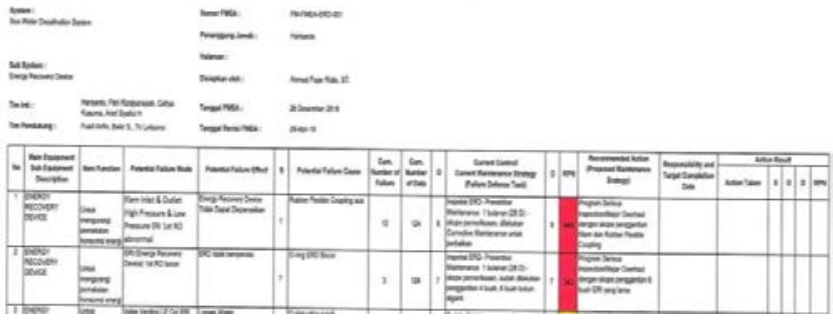

From the 6 Sub Systems that have been carried out by Interview and Brain Storming FMEA, the rating of Risk Priority Number (RPN) is conducted for 47 Failure Modes and adjusted for the Risk Categories that have been designed, with 14 Failure Mode Major Risk Risk Categories as presented in the Table 12 below:

\begin{tabular}{|c|c|c|c|c|}
\hline $\begin{array}{l}\text { Pering } \\
\text { kat } \\
\text { RPN }\end{array}$ & $\begin{array}{l}\text { Kode Sub } \\
\text { System }\end{array}$ & Failure Mode & RPN & $\begin{array}{c}\text { Kategori Risiko } \\
\text { (Risk } \\
\text { Categorization) }\end{array}$ \\
\hline 1 & SCF-1 & $\begin{array}{l}\text { Self Cleaning Filter UF Differential } \\
\text { Pressure High }\end{array}$ & 567 & Major Risk \\
\hline 2 & FPROCF-1 & Safety Filter 1ST RO B DP High & 560 & Major Risk \\
\hline 3 & SCF-2 & Membran SCF UF Bocor & 504 & Major Risk \\
\hline 4 & MAC-1 & MAC kotor & 448 & Major Risk \\
\hline 5 & UFD-1 & $\begin{array}{l}\text { UF Backwash Filter Differential Pressure } \\
\text { (DP) High }\end{array}$ & 448 & Major Risk \\
\hline 6 & ERD-1 & $\begin{array}{l}\text { Klem Inlet \& Outlet High Pressure \& Low } \\
\text { Pressure ERI 1st RO abnormal }\end{array}$ & 448 & Major Risk \\
\hline 7 & MAC-2 & $\begin{array}{l}\text { Line injeksi chlorine }(\mathrm{NaClO}) \text { pada MAC } \\
\text { bocor }\end{array}$ & 392 & Major Risk \\
\hline 8 & UFD-2 & Vessel UF Bocor & 392 & Major Risk \\
\hline 9 & MAC-5 & $\begin{array}{l}\text { Turbidity online analyzer outlet MAC tidak } \\
\text { menunjukan pembacaan yang akurat }\end{array}$ & 343 & Major Risk \\
\hline 10 & ASF-1 & $\begin{array}{l}\text { Turbidity online analyzer Air Scouring } \\
\text { tidak menunjukkan pembacaan yang akurat }\end{array}$ & 343 & Major Risk \\
\hline 11 & ERD-2 & $\begin{array}{l}\text { ERI (Energy Recovery Device) } 1^{\text {st }} \text { RO } \\
\text { bocor }\end{array}$ & 343 & Major Risk \\
\hline 12 & MAC-6 & MAC - Mud Valve Abnormal & 343 & Major Risk \\
\hline 13 & MAC-3 & $\begin{array}{l}\text { Clarifier washing draining valve MAC B } \\
\text { tidak bisa open }\end{array}$ & 343 & Major Rick \\
\hline 14 & MAC-4 & $\begin{array}{l}\text { Pressure Gauge for Sludge Pump MAC tdk } \\
\text { akurat }\end{array}$ & 343 & Major Risk \\
\hline
\end{tabular}

From the results of the Risk Priority Number (RPN) above, the results of the mapping (Risk Priority Number Mapping) using the Three Dimensional Matrix as shown in the Figure 6 below: 


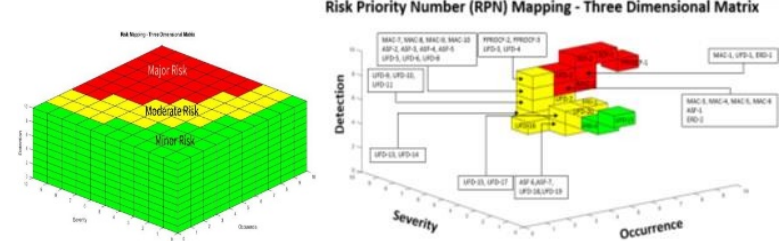

Figure 6. Mapping Results of RPN (RPN Mapping - Three Dimensional Matrix) for Each Failure Mode on the Sea Water Desalination System of the PLTU Paiton Baru (1 x 660 MW)

\section{CONCLUSIONS}

Based on the results of the Effectiveness Analysis of Implementation of Failure Mode \& Effect Analysis Method along with the Failure Defense Task for Reliability Management Improvement in the Sea Water Desalination System PLTU Paiton Baru(1x660MW), the implementation is still not effective with the following data:

a. According to the evaluation results of the site visit at UBJOM Paiton Baru PLTU on Main Equipment and Sub-equipment Sea Water Desalination System, that of the 21 Sub Systems in the Sea Water Desalination System using Reverse Osmosis Technology, only 7 SubSystems have been carried out by FMEA Workshop and FDT or $33.3 \%$ of the total Sub-System, and 14 SubSystems have not done FMEA and FDT Workshop or $66.6 \%$ of the total Sub-System.

b. Based on further research on the results of the FMEA and FDT Workshop on 5 Sub-systems namely Mechanical Accelerated Clarifier, Air Scouring Filter, Self Cleaning Filter, Ultra Filtration Device, the following things can be Energy Recovery Devices:

1) FMEA Workshop conducted by UBJOM Paiton Baru PLTU, has not identified Severity, Occurrence, and Detection levels, as well as the calculation of Risk Priority Number (RPN) as is generally done according to the literacy used (reference books and international journals).

2) To determine Failure Mode is not based on historical data from Operator Damage Report, but the source is based on Manual Book, PM Base, Existing Unit, and Browsing the Internet, so there is no data in identifying Failure Mode.

3) For Failure Defense Task with $1 Y$ interval (Annual), that is an Overhaul with several types of inspections that have not been implemented/ executed (there is no Standard Job Annual Inspection) for Mechanical, Electrical, Control \& Instrumentation scope which includes dissasembly, Visual Inspection, repair or replacement if required according to the results of the Visual Inspection, testing, I/O Check, and calibration, so that FDT with Frequency $1 \mathrm{Y}$ has not been effective. c. The Administration and HR Section, that the Engineering Supervisor and Staff especially those who are authorized to carry out the workshop process and the implementation of FMEA and FDT on the Sea Water Desalination System, namely the System Owner Common \& Auxiliary Sub-Division have never received training on FMEA.

d. Based on the evaluation of the contents of the Guidelines for Policy of PT Pembangkitan Jawa Bali No. 122.K/020/DIR/2016[5] concerning Implementasi Manajemen Aset Pembangkitan PT Pembangkitan Jawa Bali, in Chapter 4.5 concerning Reliability Management, there is no detailed guidance regarding FMEA's Standard Failure Mode \& Effect Analysis Format that must be used, and how the analysis process.

Based on the results of the Interview and Brain Storming Failure Mode and Effect Analysis (FMEA) process through FDT which has been harmonized with reference books and international journals conducted through the Workshop in 6 Sub-Systems that discuss the following things followed:

a. Based on the calculation of Risk Priority Number (RPN) on Failure Mode - Failure Mode, which is identified and assessed Severity, Occurrence, and Detection Level, it has been mapped 14 Failure Modes with Major Risk risk categories according to Ranking based on RPN.

b. 31 Failure Modes have been mapped with the Moderate Risk and 2 Failure Mode risk categories with the Minor Risk risk category according to the Ranking based on the RPN and the RPN (RPN Mapping) has been mapped using the Three Dimensional Matrix.

c. From the 47 Failure Modes that have been mapped with the Major Risk risk category according to the rating based on the RPN, a proposed Strategy Maintenance proposal (Proposed Maintenance Strategy) is proposed as an effort to reduce the risk value based on the results of Review and Evaluation of Existing FMEA and FDT Workshop Data and Results of Equipment Condition Analysis with Maintenance Strategy.

\section{REFERENCES}

M. Modarres, M. Kaminskiy, and V. Krivtsov, Reliability Engineering and Risk Analysis: A Practical Guide, 3rd edition. Boca Raton, Florida: CRC Press, 2017.

[2] C. S. Carlson, Effective FMEAs: Achieving Safe, Reliable, and Economical Products and Processes Using Failure Mode and Effects Analysis. Hoboken, N.J. : John Wiley \& Sons, 2012.

[3] D. H. Stamatis, Failure Mode and Effect Analysis: FMEA From theory to Execution, 2nd ed. Milwaukee Wisc.: ASQ Quality Press, 2003.

[4] J. Campbell, A. Jardine, and J. McGlynn, Asset Management Excellence - Optimizing Equipment Life-Cycle Decisions. Florida: Taylor \& Francis Group, 2011.

[5] Keputusan Direksi PT Pembangkitan Jawa Bali No. 122.K/020/DIR/2016 tentang Implementasi Manajemen Aset Pembangkitan PT Pembangkitan Jawa Bali. 